\title{
The Origin of the Mayoralty of London
}

\section{J. H. Round M.A.}

To cite this article: J. H. Round M.A. (1893) The Origin of the Mayoralty of London, Archaeological Journal, 50:1, 247-263, DOI: 10.1080/00665983.1893.10852582

To link to this article: http://dx.doi.org/10.1080/00665983.1893.10852582

$$
\text { 曲 Published online: } 15 \text { Jul } 2014 .
$$

Submit your article to this journal 중

Q View related articles $₫$ 
THE ORIGIN OF THE MAYORALTY OF LONDON.

BY J. H. ROUND, M.A.

In undertaking to read, at a London Congress, a paper on "the origin of the Mayoralty of London," I find myself rather in the position of Balaam when he accepted Balak's invitation. The seven hundredth anniversary of the famous Mayoralty of London was, four years ago, commemorated by its venerable Corporation, who thereby proclaimed urbi et orbi that 1189 was the year that saw its birth. Now it will be this evening my chief object to destroy this ancient illusion, and to show that the earliest year in which a Mayor is mentioned, so far as is yet known to us, is that of which this is the seventh centenary, namely 1193.

How many Londoners, we wonder, have any conception of the circumstances under which their Mayoralty actually came into being? If there be any distinctively English potentate it is surely, in the eyes of foreigners, the redoubtable Lord Mayor ; if there be any office of solemn respectability, it is surely the Mayoralty of London. And yet the "Mayor," in origin as in name, is wholly and purely a foreign importation, while his office preserves the memory of the triumph of the "Commune" in London, to which revolutionary episode it owes its birth. But the true story of its origin, exciting and instructive though it be, is wholly obscured and misrepresented by the view which has been unfortunately adopted that it dates from 1189.

Occupying as it did, among English towns, a position apart, in wealth as in importance, London had a municipal development of her own, a development of which our best modern historians can only tell us that it is "obscure." That obscurity, however, has been sadly increased by the imperfect study and the misapprehension of her great Charters of Liberties. Broadly speaking, and disregarding voL. $\mathbf{L}$. 
for the moment the statements of our accepted authorities, the great want of London, in her early days, was an efficient, homegeneous government of her own. The Cityfor the City was then London-found itself, in fact, during the Norman period, in the same plight as greater London found itself in our own days. "The ordinary system of the parish and the township," as an accomplished writer puts it, "the special franchises and jurisdictions of the great individual landowners, of the churches, of the gilds,all these were loosely bundled together." For the cause of this state of things we should have to go back to the origins of our history, to shew that the genius of the Anglo-Saxon system was ill-adapted-or rather, wholly unsuitable to urban life, that while of unconquerable persistence and strength in small, manageable rural communities, it was bound to, and did, break down when applied to large and growing towns whose life lay, not in agriculture, but in trade. In a Parish, in a "Hundred," the Englishman was at home; but in a town, and still more in such a town as London, he found himself, for administrative purposes, at his wits' end.

The practical nature, however, of our forefathers endeavoured to make the best of the means it had at hand, and to work London, as nearly as possible, on the lines of a County. Thus the Sheriff became its chief officer, and the vestry government, as we may term it, of the time found in him the sole exponent of London's unity. Had the municipal development proceeded on these lines it would have given us results very different from those which were eventually obtained; for the idea of a "Corporation" was wholly alien to administration on County principles.

But in the meanwhile, the great movement in favour of municipal liberties, which was so prominent a feature of the twelfth century, was spreading like wildfire through France and Flanders, and London which, since the coming of the Normans, had become far more cosmopolitan, was steadily imbibing from foreign traders the spirit and enthusiasm of the age. But this by no means suited the views of the crown, which here, as in Germany, looked askance on this alarming and, too often, revolutionary movement. When the history of London at this period 
comes to be properly studied it will be found that the growing powers of the Londoners, who had practically seated Stephen on the throne and had chevied the Empress Matilda from their midst, were sharply checked by her son, Henry the Second, whose policy, in this respect at least, was faithfully followed by his successor, Richard the First. The assumption, therefore, that the Mayoralty of London dates from Richard's Accession (1189) is an absolute perversion of history. There is record evidence that completely confirms the memorable words of Richard of Devises, who declares that on no terms whatever would King Richard or his father have ever assented to the establishment of the "Commune" in London. But what was this dreaded "Commune," this " new and horrible thing," as Guibert de Nogent had described it at the time of its first appearance? Our friend, Richard of Devizes, gives us his view of the subject. The Commune, he says, was "the uprising of the people, the terror of the Kingdom, and the ruin of the clergy." As a matter of fact the "sworn Commune," to give it its right name,-for the oath sworn by its members was its essential feature - was the association or "conspiracy," as we choose to regard it, formed by the inhabitants of a town that desired to obtain its independence. And the head of this association or "Commune" (which originated in French and Flemish Flanders) was given in France, the title of "Maire." For the history of that name, one must go back to these whom Mr. Freeman loved to term the Merwings ; but the fact remains that the "Mayor," as known to us, has his beginning in that long conflict of the twelfth century, from which the "Communes" of France so victoriously emerged. It was at about the same time that the "Commune" and its "Maire" were triumphantly reaching Dijon in one direction, and Bordeaux in another that they took a northern flight and descended upon London. Not for the first time in her history, the Crown's difficulty was London's opportunity, and when in October. 1191, the adminstration found itself paralysed by the conflict between the king's brother John, and the king's representative, the famous Longchamp. London finding that she held the scales, promptly named the concession of a "Commune" as the price of her support. The chroni- 
clers of the day enabled us to picture to ourselves the scene, as the excited citizens who had poured forth overnight, with lanterns and torches, to welcome John to the capital, streamed together on the morning, of the eventful 8th October, at the well-known summons of the great bell, swinging out from its campanile in St. Paul's churchyard. There they heard John take the oath to the "Commune," like a French king or lord, and then London for the first time had a municipality of her own. What the English and territorial organization could never have brought about the foreign Commune, with its commercial basis could and did accomplish.

And as London alone had her "Commune" so London alone had her Mayor. The "Maire" was unquestionably imported with the "Commune" although it is not till the spring of 1193 that the Mayor of London is first mentioned. But already in 1194 we find a citizen accused of boasting that "come what may the Londoners shall never have any king but their Mayor." It was precisely in the same spirit that the "Comuneros" of Salamanca exclaimed of their leader in 1521:-_ "Juras a Dios no haber mas Rey ni Papa que Valloria."

In importing and adopting the foreign "Maire" superimposing him, as it were, on our native immemorial Aldermen, our forefathers proved that capacity for institutional assimilation and development which the Norman element probably introduced, but which has long been one of the most valuable features in the national character of our people.

The first historian, so far as I know, to treat the subject in the modern spirit, was the present Bishop of Oxford, and it is a striking testimony to his almost infallible judgment that what he wrote on the subject a quarter of a century ago is the explanation that to this day holds the field. In his Select Charters (1870) he expressed the view that-

The establishment of the "Communa" of the citizens of London which is recorded by the historians to have been specially confirmed by the Barons and Justiciar on the occasion of Longchamp's deposition from the Justiciarship is a matter of some difficulty as the word "Communa" is not found in English town-charters, and no formal record of the act of confirmation is now preserved. Interpreted, however, by foreign usage and by the later meaning of the word "Communitas" it must be 
understood to signify a corporate identity of the municipality which it may have claimed before and which may even have been occasionally recognised but was now firmly established; a sort of consolidation into a single organized body of the variety of franchises, guilds, and other departments of local jurisdiction. It was probably connected with and perhaps implied by the nomination of a Mayor who now appears for the first time. It cannot, however, be defined with certainty. (p. 257.)

And in his Constitutional History he holds that it practically " gave completeness to a municipal constitution which had long been struggling for recognition." Mr. Coote, the next to approach the subject, contended that Dr. Stubbs" view "falls very far short of the reality." In his able paper, "A Lost Charter," "he insisted that a charter was actually granted in 1191 to the Londoners empowering them to elect a Mayor and that this is what the chroniclers meant when they spoke of the grant of "Commune," for the citizens, he urged, had possessed all the rights of a "Commune" from the days of the Conqueror. With Mr. Loftie's work came the inevitable reaction. Wholly ignoring the definite and contemporary statement as to the grant of a "Commune," he held it "far safer to adopt the received and old-fashioned opinion," and to date the Mayoralty from 1189, and as for the "Commune," he deemed it to have been of gradual growth and to have been practically recognised by the charter of Henry I.

Now, whatever the grant of "Commune" implied, it certainly implied something, and something of importance. "Upon this point there is," as Mr. Coote justly observed, "a cloud of sontemporary evidence, clear, exact, and positive." He put together the versions of the chroniclers, contemporary and well-informed (pp. 286-7), and their harmony is complete. The fact, moreover, that the "Commune" was extorted at a great crisis, proved that only when the Government was weak could so great a concession be wrung from it. Lastly, the phrase of Richard of Devizes : "Concessa est ipsa die et instituta Communia Londinensium," and that of Giraldus: "Communa seu Comminia eis concessa," correspond exactly with the formal expressions in the French Charters of "Commune." In the case of Senlis (1173) it was "Communiam fieri

1 Transactions of the London and Middlesex Arch. Soc., v, 286. 
concessimus;" in that of Campiegne (1153) "Burgensibus villæ concessimus Communiam." But if any doubt were yet possible, it would be finally removed by the words of Richard of Devizes :-

"Nunc primum indulta sibi conjuratone regno regem deesse cognovit Londonia, quam nec rex ipse Ricardus nec prædæcessor et pater ejus Henricus pro mille millibus marcis argenti fieri permississet."

There is no escaping from these words: and Mr. Loftie's theory is, consequently out of court.'

But what of Mr. Coote's? With great confidence he wrote that the "Commune," in the case of London, which had accquired all other things, expressed for its citizens the mayoralty only; nothing else was asked or desired by them, for it was the sole privilege, which was wanting to their burghal independence" (p. 287). We find, however, that, on the continent, tlie word "Commune" did not of necessity, imply a Mayor, for Beauvais and Compiegne, although constituted "Communes," had no Mayor during most of the twelfth century, the chroniclers therefore, had they only meant to speak of the privilege of electing a Mayor, would not have all employed a word which did not connote it, but would have said what they meant. Moreover, his theory rest on the assumption, common till now to all historians, that the citizens had continuously possessed, from the beginning of the twelfth century, the privileges granted in the charter of Henry I. But I have shown in my Geoffrey de Mandeville, that these privileges were not renewed by Henry II. or Richard I., and that this fact strikingly confirms the explicit words of Richard of Devizes, when he states that neither the one nor the other would have allowed the Londoners to form a "Commune" even for a million of marks. It was not till John's accesstion that the citizens at length regained the privileges granted by Henry I. By this discovery the problem is altogether changed, and the municipal development of London, it has been said, revolutionised.

I have also shewn in the same work that the citizens seem to have profited by the crisis of 1141 , as by that of

1 Mr. Loftie's argument (London, p. 53), that Glanville's words prove that London, if not other towns as well, had already a "Commune" under Henry II. is disposed of by $\mathrm{Dr}$. Gross (The Gild Merchant, i, p. 102). 
half-a-century later, to set up a " sworn commune" hoping, no doubt, by this means to regain the privileges they had lost. Here then we have a complete explanation of their aims in 1191, and of the importance that the chroniclers unanimously attach to their success.

The test which I applied to the chroniclers' statements and by which I traced the fortunes of the struggle between the Londoners and the Crown was that firma of $£ 300$ on which they insisted throughout, while the Crown endeavoured to exact over $£ 500$. Now in the Pipe-Roll of 1 Ric. I. we find the firma, as under Henry II, to be between $£ 520$ and $£ 530,{ }^{1}$ but in the Pipe Roll of two years later we suddenly meet with this bold entry:"Cives Londoniæ-Willelmus de Haverhull et Johannes Bucuinte pro eis-reddunt compotum de CCC libris blancis pro hoc anno." This triumphant return to the sum conceded in the charter of Henry I. at the crisis of 1191 confirms my view as to what the citizens desired to gain by the "Commune." It comes as a welcome fact, where all is so obscure. In the following year, 4 Ric. I., we find the firma again amounting to about $\mathfrak{L}^{*} 300^{2}$; but until the Pipe Rolls of the reign are in print, we cannot speak positively as to the endurance of this arrangement. The entries on them at the time of Richard's return from captivity record heavy payments by leading citizens,

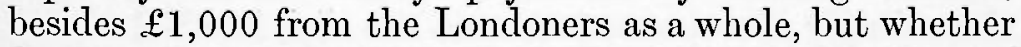
for forgiveness, for aid to ransom, or for confirmation of liberties it is hard to say, as all these reasons are grouped together.

That their "Commune" is not heard of again shews, in my opinion, that, as half-a-century before, the movement was not permanent. Neither in the regal charters, nor in the Pipe Rolls of the reign, can I find any traces of a change in the City's government All that remained of it was the appearance, the first appearance, of a Mayor of London.

It is not, as is well known, till 1215 that the right to elect a Mayor was formally conreded by John; and it is significant that this concession, like that of the "Commune" itself twenty-three years before, was made by him only at a crisis of his fortunes, when seeking to attach the

\footnotetext{
$1 £ 5282 z$, as I make it.
}

$2 £ 30617 \mathrm{~s}, 2 \mathrm{~d}$, as I make it. 
Londoners to his side. Here then, again, we must not say that such a concession was a mere form, of no value to the citizens. There had been a Mayor of London, no doubt, for twenty years, but he had never been formally recognised as the head of the City by the Crown. How truly English the position was! Just as now, the Prime Minister-indeed, one may say the Cabinet-possesses the actual executive power, although the Constitution does not recognise its existence, so must the Mayor, for all those years, have held his position in London without its ever receiving a formal recognition by the Crown. From the days of the Anglo-Saxon gilds to those of the Chamber of arbitration, a creation of yesterday, Englishmen have always been able, by the principle of voluntary association, to supply what was wanting in their existing institutions, and to carry out their great tradition of self-government. It was thus, I take it, that the Mayor maintained his power, "broad-based up on the people's will."

A most singular case of the early occurrence of a Mayor is found at Lincoln in 1222. King John. by his charter (1200) had made the concession :-

Præterea volumus et concedimus quod idem cives nostri Lincolniæ per commune consilium civitatis eligant duos de legalioribus et discretioribus civibus Lincolniæ, et præsentent eos capitali justitiæ . . . . qui bene et fideliter custodiant præposituram civitatis Lincolniæ, etc.

Accordingly, as representatives of the city, in 1222 :-

Ballivi civitatis Lincolnix summoniti fuerunt ad respondendum Burgensibus de Beverlaco. ${ }^{1}$

But the two bailiffs are thus described :-

Et naajor Lincolnie et Robertus filius Eudonis ballivi Lincolnie veniunt et defendunt etc.

The editor, indeed, suggests that "some other name must be missing," but the meaning is, evidently, that the senior "bailiff" was styled "Mayor of Lincoln."

This should be compared with a similar anomaly noted by Mr. W. H. Stevenson in his report on the "Gloucester Corporation Records": :-

"A noteworthy circumstance is that although the office of Mayor of Gloucester was not created until 1483, one Richard the Burgess is

1 Bracton's Note Book (Ed. Maitland), ii, 121.
2 th Appendix to 12th Report on Hist. MSS., p. 409. 
frequently described in the witness clauses as 'tunc Majure de Glouc. The dates of these deeds range between circa 1220 and circa 1240 . Sometimes this appears to be a title of the senior Bailiff as Richard Burgess and Thomas Ouenat are described as Bailiffs in a deed of circa 1230 , but in another deed of the same date, Burgess is called "Major" and Onenat "Bailiff" .. . The title of "Major" does not appear to have been applied to anyone else; and Richard Burgess seems to have held the title for a number of years. In a deed below, circa 1230, he is mentioned as a member of the Gild Merchant, but he is not described as "Major," so that the title does not, apparently, relate to the headship of the Gild Merchant."

Perhaps, however, the most instructive parallel to the case of London is afforded by Bristol, where a stray "Mayor" occurs, it is said, in 1200, and Mayors in regular succession from 1217, while its two reeves, stewards, or bailiffs correspond with the "Sheriffs" of London. At Bristol, as at London, the Mayoralty appears to have been an independent growth.

Mr. Loftie's suggestion that, "when Richard, in the beginning of his reign, showered charters on the English boroughs, in order to obtain money for his great expedition, it is more than probable that London was not left out,"and that the mayoralty may have been created then, is on every ground inadmissible. The succession of London charters is thoroughly well established, and that of 1194 , the earliest granted by Richard, does but jealously confirm that of his father. We see that, as Richard of Devizes asserts, he was bitterly averse to enlarging the liberties of the citizens. It is not to him, therefore, that the grant of a mayoralty must be traced. We can only trust the authentic evidence of contemporary chroniclers and records; and this is what they tell us. Howden says that the Mayor of London was appointed as one of the treasurers of the fund raised for the ransom of King Richard in April 1193, and it is obvious that at such an emergency the Government would gladly accept his help. As to records, it is our Chairman [Mr. Lyte] who is entitled to the credit of making accessible most of those in which the Mayor appears. In his well-known report on the MSS. at St Paul's, which has thrown so much light on the early history of London, and in the admirable Calendar of Ancient Deeds, published, under his superintendence, by the Public Record Office, Mr. Maxwell Lyte has given us the means vOL. $L$. 
of going thoroughly into the subject, and by his courtesy I have been able to inspect the proof-sheets of the forthcoming volume. I have, therefore, an exceptional acquaintance with all the deeds in which the Mayor figures, and I can state that no mention of the office has yet been found in them of earlier ascertained date than 1194 .

It cannot be insisted on too strongly that the chronicle of the Mayors and Sheriffs of London (in the Liber de Antiquis Legibus) is the sole authority for the creation of the Mayoralty in 1189 and that this chronicle is neither contemporary nor accurate. ${ }^{1}$ As a matter of fact, when the citizens were summoned to assemble in the old Guildhall-7 October, 1191 - to decide on their attitude towards John they were not summoned thither by a Mayor, but by a leading citizen, Henry de Cornhill, nor does any chronicler mention a Mayor at the time. ${ }^{2}$

We see, then, that everything confirms the Bishop of Oxford's theory that the office is, at least, not of earlier date than the grant of "Commune"-whatever it meantin 1191. And, therefore, it is to the Continent that historians ought to look for the true origin and meaning. of this institutional development.

The beffroi of France, to which the jurat looked as the symbol and pledge of independence, is found here also in the bell-tower of St. Paul's, which is styled in documents either by that name (berefridum), or by that of campanile, which brings before us at once the storm-tost commonwealths of Italy. It was indeed from Italy that the fire of freedom spread. With the rise of mediæeval commerce it was carried from the Alps to the Rhine and quickly burst into flame among the traders and craftsmen of Flanders. Passing into Picardy, it crossed the channel, according to a theory I have myself advanced, to reappear in the liberties of the Cinque Ports, with their French name, their French

1 It assigns, for instance, to the sear 1192 (i.e., i192-3), the return of Richard from his captivity (1194).

2 It is important to correct the error that Henry de Cornhill and Richard Fitz Reiner were Sheriffs at the crisis of 1191 for they had gone out of office so far hack as Mich., 1189. Miss Norgate writes :-_" At Michaelmas, 1189, the accounts were rendered by Richard Fitz
Reiner and Henry of Cornhill, both of whom continued in office till 1191 "; and she gives for her authority the Constitutional History of Dr. Stu'jbs. But she has misunderstood his worls. Mr. Loftie also (Historic Towns, Londo.i, pp. 42,56$)$, clearly thought these two magnates to have been Sheriffs in 1191, whereas the evidence of the Pipe Rolls is conclusive to the contrary. 
"serements," and their French jurats. ${ }^{1}$ Foreign merchants had brought it with them to the port of Exeter also, almost as early as the Conquest, and we cannot doubt that London as well was already infected with the movement, and eager to find in the foreign "Commune" the means of attaining that administrative autonomy and political independence which that term virtually expressed.

French historians are now agreed to reject finally the Roman theory and to see in the "Commune" a mediæval movement with the merchant gild for its "element generteur." "They have defined it with much justice as "l'association militaire et civile fondee sur le serment."3 The oath taken by its members was, indeed, its distinctive feature, and it is this oath that comes to the front in the crisis of 1191 as in the abortive attempt of half a century before. Hence we find the "Commune" termed by its opponents a "conspiracy." And thus John and the magnates were compelled to take the oath to it themselves, just as the king was compelled to take it in France." It is also now recognised abroad that the "Commune" was the stamp of complete independence, ${ }^{5}$ as distinct from the grant of commercial privileges or the confirmation of material security. And it is agreed that although there might be a "Commune" without a maire, the possession of a maire crowned the edifice and implied a more perfect type. ${ }^{6}$ Mantes, which gained its "Commune" so early as 1159 , had a council of pares communitatis, but only a prévôt for its head. So, too, our own Cinque Ports had jurats before they had mayors. With us the Sheriff in London, and the Bailiff, in provincial towns, corresponded with the prevôt royal and we find the latter, in

1 Archaeological Review, iv., 366, et sq.

2 Dr. Gross's position is that "if this fraternity [the Gild] was not the germ of the English municipality, but only a potent factor in its evolution, it may be fairly presumed that the Gild's influence on the Continent was not greater" (I. 282). But the "renaissance of commerce," he admits, led to the formation of gilds. merchant, as it undoubtedly did to the spread of " communes."

${ }^{3}$ Luchaire's Histoire des Institutions Monarchiques de la France (1883), II.. 152.

' Le roi s'engage, d'ailleurs, a l'egard des bourgeois, en jurant solenellement la commune, comme les bourgeois la jurent entre eux." Luchaire (p. 179).

3 Ibid p. 149.

6 Les communes qui possedaient des l'origine non seulement un conseil elu, mais un maire, par exemple Laon, Reims, Noyon, Corbie, St. Riquier, paraissent jouir d'un certain degre d'independance. Mais nous ignorons absolument quelle part la royante prenait a la nomination du chef de la commune. II est hors de doute cependant que dans les villes le prevot royal subsistait a cote du maire" Luchaire p. 183. 
France, existing side by side with the Mayor, exactly like our own Sheriffs in the city of London. The importance of this fact lies in the distinction it enforces between the office and functions of the Mayor, and those of the more ancient officers, the Sheriffs. The special need, for London, of a Mayor arose, I take it, from the want of some symbol of the City's unity, some central figure around which the corporation of the future could be grouped. The Crown might sullenly postpone the hour of official recognition, but it knew that through the mouth of her Mayor, its City of London spoke.

Hostile though our kings might be to the communal movement here, they favoured it, for purposes of their own, in their Norman dominions. M. Giry, the chief authority on the subject, traces, indeed, the "Communes" of Normandy, in large part, to the royal tie. This is a factor in the problem that we cannot afford to overlook, considering the peculiar relation in which Normandy stood to England.

As M. Langlois has recently observed :-

"Jamais en effet la France et l'Angleterre n'ont ete, meme de nos jours, aussi intiment en contact de ... Jusqu'a la fin du xii ${ }^{\text {nd }}$ sie, les deux pays eurent a peu pres les memes institutions politiques, ils pratiquaient la meme religion, on y parlait la meme langue. Des Francais allaient frequemment dans l'île comme touristes, comme colons, comme marchands" (Revue Historique).

Was it then from Normandy that the communal idea most directly reached London? We are apt to forget the close connections between the two capitals of our AngloNorman Kings, London on the Thames and Rouen on the Seine. A gifted writer has referred to those "citizens of Norman origin, to whom London, in no small measure, owed the marked importance which is obtained under Henry I . . . Merchants, Traders, craftsmen of all sorts come flocking to seek their fortunes in their sovereign's newly-acquired dominions, not by forcible spoliation of the native people, but by fair traffic and honest labour in their midst. . . . Norman refinement, Norman taste, Norman fashions, especially in dress, made their way rapidly among the English burghers. . . . The great commercial centre to which the Norman merchants had 
long been attracted as visitors, attracted them as settlers now that it had become the capital of their own sovereign. ${ }^{1}$

It is known from the Instituta Londonice that so far back as the days of Fthelred the men of Rouen had traded to London, bringing in. their ships the wines of France, as well as that mysterious " craspice," which it is the fashion to render "sturgeon," although there is reason to believe that the term denoted the porpoise and even the whale. But what I shall now bring before you is a far more curious fact, a fact which has eluded, it seems, the research of our historians, both general and local. A most interesting charter of Henry the Second, granted by him, as Duke of the Normans, in 1150 or 1151 , to the citizens of Rouen, confirms them in possession of their port at Dowgate, as they had held it from the days of Edward the Confessor, with the right, if they found any ship there moored, wherever it came from, of ordering it to be removed; and after a tide had ebbed and flowed without this being done they were at liberty to set her adrift without responsibility for the damage she might receive. ${ }^{2}$ Here then we have evidence that, even before the Conquest, the citizens of Rouen had a haven of their own at the mouth of the Walbrook, a site now covered by Cannon Street station, for which they were very possibly indebted to the Norman proclivities of the Confessor.

Nor does the interest of this Rouen charter stop there. Among the sureties for the young Duke's fidelity to his word we find Richer de l'Aigle, the youthful friend of Thomas Becket, "sprung." as Miss Norgate writes, "from one of the noblest families of Normandy, and a constant visitor and intimate friend of the little household in Cheapside." And does not the name of Becket remind us how " Thomas of London, the burgher's son," afterwards "Archbishop, saint and martyr," had for his father a Sheriff of this city, but one who was by birth a citizen of Rouen, while his mother was a daughter of Caen? Therefore the same writer is probably justified in maintaining "that the influence of these Norman burghers was dominant in the city." They seem," she adds, "to have won their predominance by fair means, and to have used it

1 Norgate's England under the Angevin Kings, i, 48-9.
${ }^{2}$ Cheruel's Histoire de Rouen pendant l'époque communale i, 245. 
fairly. They brought a great deal more than mere wealth ; they brought enterprise, vigour, refinement, culture, social as well as political progress."

Now, it is my contention that political progress was represented with them by the communal idea. Their interests, moreover, would be wholly commercial, and, therefore, opposed to those of the native territorial element. If we turn to Rouen we find its Mayor occurring fifteen years, at least, before the Mayor of London, ${ }^{1}$ and he was Mayor, remember, of the "Commune" of Rouen - "Major de Communia." For Rouen was a stronghold of the "Commune." There is a curious illustration of the close parallel between the Government of the two capitals. In the London Pipe Roll of 1130 we find the Sheriffs paying a sum of money to be relieved of their office. This proceeding is so contrary to the practice of recent, I may say of very recent times, that it has been difficult to explain. But when we glance at the Rouen charter of twenty years later we find that one of the privileges guaranteed to the citizens is that they shall not be called upon to serve as Sheriffs against their will. ${ }^{2}$

So, too, the Rouen charter aptly confirms my own reading of the London charter of Henry I. It was my suggestion that "Wardemota"-the supposed Wardmoots mentioned in the latter was only a misreading for "vadimonia" which is the word in the charter of Henry II. Now the Rouen charter of 1150 , in the parallel clauses, seems to have the word "vadimonia."

Without pressing the point too far I would urge that in this, then as now, most cosmopolitan of cities its Mayoralty was wholly of foreign origin, and resulted in men of foreign name who bore the purely English titles of Aldermen and of Sheriff accepting for their head an Englishman of the English under the foreign style of Mayor.

The origin of Henry Fitz Ailwin raises a curious question. I have demonstrated, in great detail, that the parentage assigned him by Mr. Loftie is, on every ground, impossible, ${ }^{4}$ and have suggested, in the Dictionary of

1 Bartholomew Fergant was Mayor in 1177.

Quod nullus eorum in ... vicecomitatu . . ponatur, nisi sponte sua.

3 Lowdox Charter.

Et terras suas et [vadimonia] et debita civibus meis habere faciam.

\section{Rouen Charter.}

Quod terras et empticia sua et teneuras et radimonia sua in pace teneant, et ego faciam eis reddi debita sua.

The Antiquary, March, 1887. 
National Biography, that he was identical with Henry Fitz Ailwin Fitz Leofstan who appears in the Pipe Roll of 1165 (11 Hen. II.) with his brother, Alan, as fining for land in Herts or Essex. Now we know that Henry, the Mayor, did hold land in Herts, namely, Watton, which he and his antecessores are recorded to have held by serjeanty. But when we turn to Domesday Book we find Watton held - clearly by serjeanty-by Derman a King's thegn. This, which seems to have escaped notice, brings us at once to that famous charter still preserved in the Guildhall, granted by the Conqueror in favour of his man, Derman. "It has for centuries," Mr. Loftie writes, "been an object of interest to historians and antiquaries." Now, Mr. Coote plausibly argued that the description of Derman as the King's "man" identified him with the Derman, King's thegn, of Hertfordshire, while the preservation of this charter at the Guildhall identified him further with that 'Derman of London,' who occurs in Domesday Book as holding land at Islington. Putting all this together we have, I would suggest, quite a possibility that this mysterious Englishman who enjoyed the Conqueror's favour, was the ancestor, not only in title, but in blood of the first Mayor of London, Henry Fitz Ailwin Fitz Leofstan. ${ }^{1}$

I have been able, you see, this evening to do little more than to show you how the problem now stands, and to lay stress on the foreign origin of that municipal movement which gave London her Mayor. We can only hope that some document may yet be discovered among the archives that are now so diligently explored, which will solve for us one at least of our present difficulties, by either determining the actual date at which a Mayor was first elected, or by explaining his precise status, or by enlightening us further as to the character of the "Commune," of which the constitution may have been restricted to what are now known as "the propertied classes." There are not wanting, even now, indications to that effect. And indeed it has been the special glory of the City, throughout her history, that she has shown us how to reconcile the claims of property and of true freedom. Ever faithful, in the person of her Mayors, to the cause of order, but not of tyranny,

Ancient Deeds (P.R.O.), A, 2507. 
of liberty, but not of license, she opposed the Commonwealth, as she opposed the King, and she saw her principles triumph. In the seven hundred years during which her Mayors have ruled her she has seen our dynasties rise and fall, our parties form and vanish: but her principles have never changed. Wise with the wisdom of seven centuries, strong in the knowledge of her mighty past, she upholds, as ever, with unflinching hands the cause for which she has fought so long-the cause of order and of freedom.

\section{Appendix.}

The following is a list of deeds, etc., in which the name of Henry Fitz Ailwin occurs, compiled by me. It is divided into lists of those in which he is, and those in which he is not, styled Mayor.

MaYor.

A. 1449

1474

1502

1639

1754

1775

1936

1951

2124

2125

2180

2182

2332

2335

2462

2493

2502

2507

2550

B. 1172

"Ancient Deens.

Not MaYoR.

A. 1475

1477

1679

1684

1686

1882

2103

2383

2518

St. Paul's MSS.

(Ninth Report on Historical MSS., App. I.)

p. 8

10

p. 25

20 
British Museum.

Harl. 47 , I. 7

Cott. MS. xxvii, 141

Add. 1046

Harl. 459, 67 (?)

Harl. 83 , a. 18

Harl. 50, a. 33

Harl. 52, a. 3

Public Record Office.

Rotuli Curiæ

Regis (q.v.)
Duchy of Lancaster.-Box. A, 163. Two records facsimiled by Palgrave.-Pref. to Rot. Cur. Reg.

Thus, excluding such transcripts as the testa de Nevill, we have some fifty references now available on which to base an enquiry as to the date at which Henry Fitz Ailwin actually became Mayor. It was my hope, that we might place previous to that date every document in which he is not styled Mayor. But although this hypothesis seemed highly probable, a deed such as A. 1882, of 7 Ric, I, in which he is not styled Mayor, seems to be fatal to it. We are deprived, therefore, of this simple test, and must wait until some direct evidence enlightens us further on the subject.

But, in the meanwhile, the final concord of 30 Nov., 1191, facsimiled by Palgrave, placing as it does, Henry Fitz Ailwin not only after Henry de Cornhill, but after Henry's hrothers, - and not giving him the style of Mayor -is at least strongly opposed, as I originally urged, ${ }^{1}$ to the view that he was Mayor at the time, although the "Commune" had been granted three weeks before. We must still, therefore, seek his appointment between that date and the spring of 1193. 